\title{
NORMALIZATION OF LIVER GLUCOSYLCERAMIDE LEVELS IN THE "GAUCHER" MOUSE BY PHOSPHATIDYLSERINE INJECTION
}

\author{
Subhash C. Datta and Norman S. Radin
}

Mental Health Research Institute, University of Michigan, Ann Arbor, Michigan 48109

Received March 3, 1988

A model of the human genetic disorder, Gaucher disease, can be rapidly generated in mice by the injection of emulsified glucosylceramide and an inhibitor of the lipid's hydrolase, conduritol $B$ epoxide. The liver grows rapidly as it absorbs the load of lipid but the effect disappears as new glucosidase is formed and the load is hydrolyzed. This normalization process is accelerated by treatment with phosphatidylserine, which is a known stimulator of the enzyme. It is possible that injecting the phospholipid into Gaucher patients would have a therapeutic effect since it might help them utilize their residual glucosidase to destroy stored glycolipid. 1988 Academic Press, Inc.

The enzyme that is defective in Gaucher disease, glucosylceramide $\beta$-glucosidase (E.C.3.2.1.45), is activated by two materials acting in concert, a stimulating protein and an acidic lipid, such as phosphatidylserine. Not only does PS act on the normal enzyme, it also acts on the defective enzyme in cultured fibroblasts $(1,2)$. In a study of neuroblastoma cells that were loaded with GlcCer in culture, the addition of PS to the medium considerably speeded the hydrolysis and disappearance of the GlcCer (3). This finding may mean that the glucosidase is normally not in a fully activated state and the possibility therefore exists that the defective enzyme of Gaucher patients is also not in a fully activated state. Injected phosphatidylserine has been found to enter tissues of intact animals (4) without exerting any harmful effects. If PS could be made to reach the tissues of the patients at a sufficient level it might have therapeutic value.

We have recently shown that a model form of Gaucher disease could be produced in one day in mice by injecting them with an emulsion of GlcCer (5). The relatively heavy load of glycolipid was rapidly taken up by the liver, producing the accumulation of GlcCer and glucosidase activating protein, and the organ enlargement so typical of the disorder. As noted before, the enlargement could not be attributed to edema but represented actual increase in organ mass. The phenomenon was accentuated by also injecting an inactivating inhibitor of glucosidase, conduritol B epoxide, which evidently protected the loaded lipid against hydrolysis for a while. These observations made it possible to test the "Gaucher" mice to see whether exogenous PS could accelerate the disappearance of the stored lipid.

\section{MATERIALS AND METHODS}

Materials. GlcCer and CBE were prepared here (6,7), PS was from bovine brain (Sigma Chemical). The GlcCer was emulsified with $3 / 4$ its weight of Myrj 52 (ICI America Inc.) in isotonic saline prior to

Abbreviations: GlcCer, glucosylceramide; PS, phosphatidylserine; CBE, conduritol B epoxide. 
injection at a dosage of $250 \mathrm{mg} / \mathrm{kg}$. The PS was emulsified similarly with $1 / 3$ its weight of detergent. The mice (16 day old males, strain Hsd CF1, Harlan Industries) were sorted with a computer program into weight-matched groups of three or five, having similar mean weights and weight standard deviations (8). Two or three groups, in separate cages with separate mothers, were used for each experimental test (a total of 10 or 9 mice).

Methods. The various compounds were injected i.p. and the mice were killed by cervical dislocation. The livers were washed with cold saline, wiped dry, frozen in pentane cooled with dry ice, and weighed individually. They were stored at $-65^{\circ} \mathrm{C}$, pooled in groups of three or five, then homogenized in water. Duplicate aliquots were taken for protein and DNA determination and glucosidase assay with $\left[{ }^{3} \mathrm{H}\right] \mathrm{GlcCer}$ as substrate (5). Thus the assays yielded four or six values per experimental point. Thin-layer chromatography of the liver GlcCer was quantitated by video/computer charring densitometry (9). Total lipids were determined gravimetrically with a hexane-isopropyl alcohol extract. It should be noted that the assay system for the enzyme included taurocholic acid (3), which activates glucosidase independently of endogenous activators.

\section{RESULTS}

Changes in Liver_Due to GleCer_Initially we tested the mice with a single injection of GlcCer emulsion, without CBE, to see how long the changes in liver persisted (Table 1). As observed before (5), there were striking increases in liver size, total DNA, total protein, and specific activity of glucosidase. At every time point, the glucosidase activity was significantly higher in the lipidinjected mice, compared with the controls, with a maximum increase of $42 \%$ by 2 days. Even after 7 days there was still a significant increase, although it was only $7 \%$.

While previous experiments had yielded a distinct increase in liver weight within 1 day, here it took 2 days to reach a large effect ( $33 \%$ increase). The growth stimulation disappeared during the next 2 days. (The controls show increases with time due to normal mouse growth.) The total DNA in each liver behaved similarly, reaching a value $22 \%$ above the control weights $(p<0.05$, Student $t$-test). The total protein values were significantly higher $(10 \%, \mathrm{p}<0.005)$ by 1 day and $29 \%$ higher $(\mathrm{p}<0.005)$ by 2 days. Here too the effect disappeared during the next 2 days. The GlcCer contents, evaluated by visual examination of thin-layer plates, were markedly higher in all lipid-injected mice.

In a similar experiment, in which the mice were injected with three times the usual GlcCer dose and examined only 1, 2, and 4 days afterward, thin-layer chromatography of the lipids from $0.25 \mathrm{mg}$ of liver showed that the normal liver did not contain detectable GlcCer but that the livers from GlcCerinjected mice revealed distinct spots. The maximal concentration of glycolipid was attained 2 days

Table 1

Effect of a single injection of glucocerebroside (emulsified in Myrj 52/saline) followed over time. Control mice were injected with saline only.

\begin{tabular}{lcccc}
\hline \multicolumn{1}{c}{ Group } & $\begin{array}{c}\text { Liver weight } \\
(\mathrm{mg})\end{array}$ & $\begin{array}{c}\text { DNA weight } \\
(\mathrm{mg} / \text { liver })\end{array}$ & $\begin{array}{c}\text { Protein weight } \\
(\mathrm{mg} / \text { liver })\end{array}$ & $\begin{array}{c}\text { Glucosidase } \\
(\mathrm{nmol} / \mathrm{hr} / \mathrm{mg})^{*}\end{array}$ \\
\hline 1-day Controls & $303 \pm 39$ & $1.07 \pm .03$ & $40.9 \pm 1.1$ & $4.34 \pm .07$ \\
1-day GlcCer & $316 \pm 34$ & $1.03 \pm .05$ & $45.0 \pm 1.2$ & $4.90 \pm .19$ \\
2-day Controls & $321 \pm 27$ & $1.22 \pm .04$ & $44.8 \pm 2.9$ & $4.15 \pm .18$ \\
2-day GlcCer & $426 \pm 40$ & $1.49 \pm .16$ & $57.8 \pm 4.4$ & $5.91 \pm .42$ \\
4-day Controls & $465 \pm 55$ & $1.65 \pm .11$ & $64.8 \pm 1.3$ & $4.30 \pm .05$ \\
4-day GlcCer & $436 \pm 77$ & $1.63 \pm .31$ & $61.6 \pm 11.5$ & $4.76 \pm .11$ \\
7-day Controls & $618 \pm 92$ & $2.22 \pm .15$ & $84.9 \pm 4.1$ & $4.24 \pm .03$ \\
7-day GlcCer & $584 \pm 100$ & $2.16 \pm .06$ & $82.2 \pm 1.2$ & $4.53 \pm .08$ \\
\hline
\end{tabular}

${ }^{*}$ Enzyme activity based on liver weight. 
after the injection. It is interesting that the 4-day livers, as in the other experiment, had normal weights and DNA contents yet contained about 2/3 the maximal GlcCer seen at 2 days.

Effect on Liver of GlcCer plus CBE-Since the endogenous glucosidase activity was so high after GlcCer injection, and since so much GlcCer disappeared quickly, we tried to prolong the period of high lipid concentration by inactivating the enzyme with CBE $(80 \mathrm{mg} / \mathrm{kg})$, injected with the glycolipid. Six groups of nine mice each were used. One group was injected with saline and all the remaining groups were injected with GlcCer/CBE. The saline controls and one of the lipid-loaded groups were killed 24 hr later (Group A, Fig. 1). At that point, groups B and C mice were injected with saline or $20 \mathrm{mg} / \mathrm{kg}$ of PS and Group B was killed 1 day later. Group C mice received a second saline or PS injection at that point and were killed 1 day later.

As seen before, the GlcCer/CBE injection produced rapid liver growth in $24 \mathrm{hr}$ : a $28 \%$ increase (Group A, Fig. 1). By 2 days (left bar of Group B), the liver weights were even higher (35\%); by 3 days they were $44 \%$ higher (left bar of Group $C$ ). These changes were significant at the $p<0.005$ level. Little of this growth can be attributed to normal animal growth since these GlcCer/CBE animals did not show significant differences in body weight. Thus it would appear that the CBE acted to prolong the liver growth phenomenon by prolonging the storage of GlcCer.

Effect of PS on Liver Size-When the GlcCer-loaded mice were injected with PS, there was a partial return to normal liver weights (right bar of Group B, Fig. 1). The decrease was $13 \%, \mathrm{p}<0.01$, compared with the untreated mice (left bar of Group B). However there was also a significant decrease in body weight too (12\%) so the PS effect might have involved the entire body. In the case of mice injected with PS on two successive days, the livers were $10 \%$ lighter ( $<<0.01 \%$, Group $\mathrm{C}$ ). In this case there was a negligible difference in body weight so the effect seems to have been specifically on the liver.

Lipid Changes-Measurement of the total liver lipids (Group A, Fig. 2) showed that GlcCer loading produced a significant increase in one day $(33 \%, \mathrm{p}<0.005)$. This level did not change appreciably over
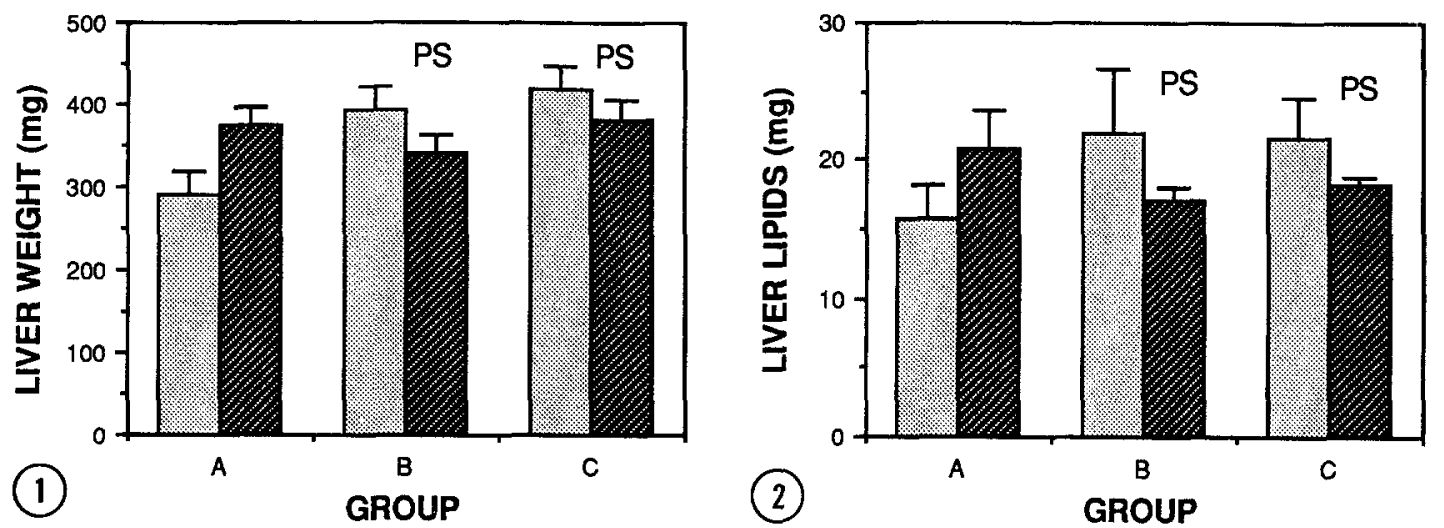

Fig. 1. Changes in liver weight following a single injection of GlCCer, $250 \mathrm{mg} / \mathrm{kg}$, and CBE, $80 \mathrm{mg} / \mathrm{kg}$, into each mouse. Each bar is based on the data from three groups of three mice each. The animals of Group A were killed 1 day after the lipid (or saline) injection; the animals of Groups B and C were killed 2 and 3 days after the initial cerebroside injection. The mice represented by the right bars received one or two injections of phosphatidylserine $(20 \mathrm{mg} / \mathrm{kg}$ ) after the glycolipid injection. The error bars indicate one standard deviation, based on nine liver weights.

Fig. 2. Changes in mouse liver total lipids following a single injection of GlcCer (same experiment as in Fig. 1). The error bars show the S.D. calculated from the six values obtained from the three subgroup of three mice each. 
the next 2 days. (left bars of Groups B and C). One day of treatment with PS produced significant lowering (23\%, comparing the two bars of Group B); 2 days of PS treatment lowered the lipids $16 \%$ (Group C). These are the effects to be expected if PS reached the liver and accelerated the hydrolysis of the stored GlcCer.

Glucosidase Changes-Measurement of the liver glucosidase activities showed the expected initial decrease in active enzyme due to reaction with CBE (Group A, Fig. 3). As observed before (5), the presence of exogenous GlcCer seems to partially protect the enzyme against the inhibitor and to induce much faster synthesis of the enzyme than one sees with $C B E$ alone (10). As the liver synthesized new glucosidase molecules during the next 1 and 2 days the enzyme level came closer to normal although it was still not significantly recovered (compare the left bars of all three groups).

Injection of PS, once or twice, acted to increase the glucosidase activity and bring it closer to normal. The increase was $10 \%$ above the controls after a single PS injection (compare the two bars of Group B, $p<0.01$ ); after two injections the increase was $20 \%$ (compare the two bars of Group $C, p<0.01$ ).

Glucocerebroside Changes-Determination of the liver GlcCer from the same animals showed the expected heavy uptake of the lipid (Group A, Fig. 4). The content remained steady over the next 2 days (left bars of all three groups). PS injection had a large effect on the rate of GlcCer disappearance. The single injection led to a $58 \%$ decrease in total amount per mouse (compare the two bars of Group B), and two PS injections led to a $69 \%$ decrease (Group C).

Control Experiment-To determine whether the effect of PS on glucosidase was the result of direct reduction in the amount or activity of the enzyme, rather than to the assumed mechanism (acceleration of the normal hydrolysis of stored GlcCer), we injected groups of nine normal mice at time zero with saline or PS emulsified with Myrj (Table 2). One day later the injections were repeated and the mice were killed $5 \mathrm{hr}$ later. Three dosages of PS were used: 10,20 , and $50 \mathrm{mg} / \mathrm{kg}$ body weight. The PS-treated mice showed no significant change in body weight ( $6.2 \mathrm{~g}$ aver.), liver weight (213 $\mathrm{mg}$ aver.), or liver lipid concentration $(65 \mathrm{mg} / \mathrm{g})$. The glucosidase specific activities showed negligible but significant decreases (3\% and $4 \%, \mathrm{p}<0.05$ ) in the animals given 20 and $50 \mathrm{mg} / \mathrm{kg}$. These findings indicate that PS in
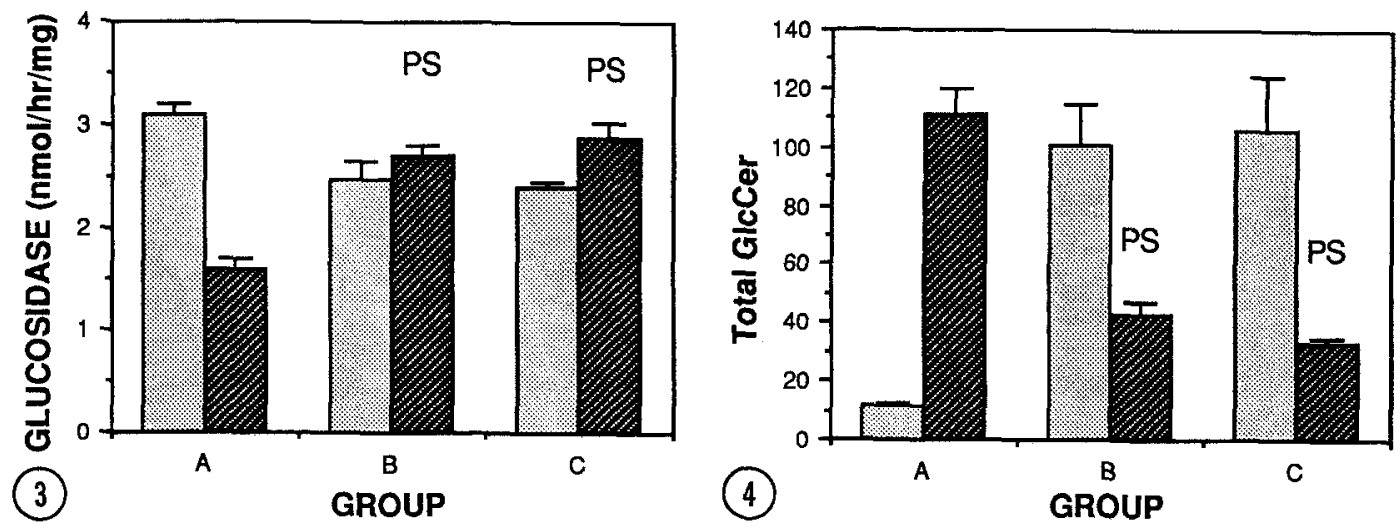

Fig. 3. Changes in GlcCer glucosidase specific activity in livers of mice injected with GlcCer/CBE and/or PS (same experiment as in Fig. 1). The error bars indicate the standard deviation calculated from the six assay values obtained.

Fig. 4. Changes in total liver GlcCer content ( $\mu \mathrm{g} /$ liver) from the mice described in Fig. 1. 
Table 2

Effect of phosphatidylserine injection into normal 16-day old mice. The mice were injected with either saline or a PS emulsion in Myrj/saline, then reinjected with the same dose $24 \mathrm{hr}$ later and killed after 5 hr. The values shown are means and standard deviations.

\begin{tabular}{lccc}
\hline $\begin{array}{c}\text { Dose } \\
(\mathrm{mg} / \mathrm{kg})\end{array}$ & $\begin{array}{c}\text { Body weight } \\
(\mathrm{g})\end{array}$ & $\begin{array}{c}\text { Liver weight } \\
(\mathrm{mg})\end{array}$ & $\begin{array}{c}\text { Glucosidase activity } \\
(\mathrm{nmol} / \mathrm{hr} / \mathrm{mg})\end{array}$ \\
\hline & & & \\
0 & $6.13 \pm 0.33$ & $207 \pm 20$ & $3.35 \pm 0.08$ \\
10 & $6.35 \pm 0.38$ & $217 \pm 25$ & $3.32 \pm 0.06$ \\
20 & $6.18 \pm 0.34$ & $210 \pm 22$ & $3.26 \pm 0.05$ \\
50 & $6.30 \pm 0.35$ & $220 \pm 25$ & $3.22 \pm 0.04$ \\
\hline
\end{tabular}

normal, unloaded mice has only a minor effect on GlcCer metabolism and liver size, and that it does not induce an elevated glucosidase activity.

\section{DISCUSSION}

An interesting observation was made in the time studies (without PS), namely the return to normal liver size despite the continued presence of an elevated level of GlcCer. This may be the result of gradual confinement of the stored lipid to a non-stimulatory location in liver cells. A study in rats of the tissue distribution of injected L-GlcCer (the inert isomer of the natural glycolipid) showed that much of the material ended up in liver cells (11). Release from Kupffer cells (which store most of the GlcCer in Gaucher disease) was slow when compared to other liver cells. If the natural enantiomer used in our experiments behaved similarly, one could attribute the growth stimulation phenomenon to uptake by hepatocytes.

The pharmacology of PS is still little known so alternative explanations of its effects on liver size, GlcCer levels, total lipids, and $\beta$-glucosidase might be offered. Phosphatidylserine can enter the organs of intact animals (4) and affect brain levels of glucose and neurotransmitters (12-14). Effects on prolactin secretion and turnover of phosphatidylinositol were observed (15). Improvement in learning by rats was reported (16). Some of the observed changes have been attributed to conversion of PS to lysoPS. The empirical observation that we report here, of relevance to Gaucher therapy, is that a PS emulsion can help to get rid of stored GlcCer.

ACKNOWLEDGMENT : This work was supported by grant NS 03192 from the U. S. National Institutes of Health. The author, NSR, is a Senator Jacob Javits Investigator awardee.

\section{REFERENCES}

1. Choy, F. Y. M. (1984) Human Genet. 67, 432-436.

2. Gatt, S., Dinur, T., Osiecki, K., Desnick, R. J. and Grabowski, G. A. (1985) Enzyme 33,109-119.

3. Datta, S.C., Snider, R.M., and Radin, N.S. (1986) Biochim. Biophys. Acta 877, 387-398.

4. Toffano, G., Battistella, A., Mazzari, S., Orlando, P., Massari, P., and Giordano, C.(1982) In Phospholipids in the Nervous System (L.A. Horrocks, G.B. Ansell, and G. Porcellati, eds.), Vol. 1, pp. 173-180. Raven Press, New York, NY.

5. Datta, S.C., and Radin, N.S. (1986) Lipids 21, 702-709.

6. Radin, N.S. (1976) J. Lipid Res. 17, 290-293. 
7. Lee, K.J., Boyd, S.A., and Radin, N.S. (1985) Carbohydr. Res. 144, 148-154.

8. Radin, N.S., and Klinger, P. (1986) Comp. Applic. Biosci. (CABIOS) 2, 107-109.

9. Ford-Holevinski, T.S., and Radin, N.S. (1985) Anal. Biochem. 150, 359-363.

10. Hara, A., and Radin, N. S. (1979) Biochim. Biophys. Acta 582, 412-422.

11. Tokoro, T., Gal, A. E., Gallo, L. L., and Brady, R.O. (1987) J. Lipid Res. 28, 968-972.

12. Bruni, A., Toffano, G., Leon, A., and Boarato, E. (1976) Nature, Lond., 260, 331-333.

13. Toffano, G., Mazzari, S., Zanotti, A., and Bruni, A. (1984) Neurochem. Res. 9, 1065-1073.

14. Mantovani, P., Aporti, F., Bonetti, A.C., and Pepeu, G. (1982) In Phospholipids in the Nervous System (L.A. Horrocks, G.B. Ansell, and G. Porcellati, eds.), Vol. 1, pp. 165-172. Raven Press, New York, NY.

15. Bonetti, A.C., Bellini, F., Calderini, G., Galbiati, E., and Toffano, G. (1987) Neuroendocrin. 45, 123129.

16. Corwin, J., Dean III, R.L., Bartus, R.T., Rotrosen, J., and Watkins, D.L. (1985) Neurobiol. Aging 6, 1115. 